\title{
A NeMZeTI ALAPTANTERV ÉS A PEDAGÓgUSKÉPZÉS ÖSSZEFÜGGÉSEI
}

\author{
VASS VILMOS \\ a Pannon Egyetem Bölcsészettudományi Kar Neveléstudományi Intézet \\ Tanárképző Központjának vezetője, egyetemi docense \\ vassv@almos.vein.hu
}

Az elsö Nemzeti alaptanterv (Nat) elkészitése (1995) és bevezetése (1998 óta), majd az azt követö két felülvizsgálat $(2003,2007)$ után számos elöadás, tanulmány, elemzés foglalkozott a Nat és a pedagógusképzés (óvó-, tanitó- és tanárképzés) összefüggéseivel. Megszülettek és a pedagógusképzés gyakorlatában megjelentek azok a modellek és programok, amelyek figyelembe vették a Nemzeti alaptanterv alapelveit, célkitüzéseit, tágabb értelemben a közoktatás tartalmi reformjának változásait. Az utóbbi bö tíz év tapasztalatai lehetôvé teszik, hogy tanulmányom elsö részében - a teljesség igénye nélkül - elemezzem a Nemzeti alaptanterv fejlödéstörténetét és az ezzel párhuzamosan zajló pedagógusképzési folyamatokat. A tanulmány második része a Nat-2007 és a pedagógusképzés összefüggéseire, a közeljövö legfontosabb feladataira, területeire fókuszál.

\section{A Nat-evolúció ${ }^{1}$}

A Nat-evolúció történetéről számos kitünő elemzés született. ${ }^{2}$ A szerzők egyetértettek abban, hogy a Nemzeti alaptanterv a hazai tantervi-tartalmi szabályozás jelentős, meghatározó dokumentuma. Ballér Endre elsősorban a nevelés értékrendszerét és tartalmát nagymértékben befolyásoló gazdasági és társadalmi változások, a hazai oktatási rendszer átalakulása, az iskolai műveltség és tudás tartalmára, közvetítésére vonatkozó igények és az elért eredmények közötti ellentmondások szempontjai szerint elemezte az 1995-ös Nemzeti alaptantervet. Báthory Zoltán a kilencvenes évek „reform-hullámvasútjára” kalauzolta el az olvasót és követte nyomon a tantervi-tartalmi szabályozás változásait. Szebenyi Péter a Nat-1995 számos korábbi változatainak, munkaanyagainak segítségével a tantervkészítés hazai buktatóit mutatta be. Az elemzések egyik „közös többszöröse” azonban a Nemzeti alaptanterv és a pedagógusképzés összefüggése volt. Minden szakember egyetértett abban,

\footnotetext{
${ }^{1}$ A kifejezést Báthory Zoltán használta először a Nat Implementációs Bizottság 2008. februári ülésén. ${ }^{2}$ A teljesség igénye nélkül: Ballér Endre (2003): A tanterv. In: Falus Iván (Szerk.): Didaktika. Elméleti alapok a tanitás tanulásához. Nemzeti Tankönyvkiadó, Budapest, 191-218., Báthory Zoltán (2001): Maratoni reform. A magyar közoktatás reformjának története, 1972-2000. ÖNKONET Kiadó, Budapest, Szebenyi Péter (1994): Tantervkészítés egykor és most. Educatio, 1994 3. sz. 345-354.
} 
hogy az alaptanterv bevezetetése, megvalósítása hat a pedagógusképzés és -továbbképzés tartalmára (tantervelméleti és -fejlesztési kurzusok). Ahogy Ballér Endre 1994 áprilisában a kazincbarcikai országos tanácskozáson megtartott előadásában fogalmazott: „Az országos, regionális és helyi szinten egyaránt, mind a pedagógusképzés, mind a szervezett önképzés és továbbképzés keretei között egyre nagyobb fontosságot tulajdonítanak a pedagógusok tantervkészítö-fejlesztő hozzáértésének, felkészültségének a megalapozására, növelésére.” (Ballér, 2004, 161. o.) A továbbképzések tartalmi struktúrájának átalakítása fontos szempont volt a Nat-1995 implementációjában. Pöcze Gábor 1995-ben megjelent tanulmányában (Pöcze, 1995) célcsoportok szerint megadja a továbbképzések javasolt programját. A „tantervkészítő-fejlesztö hozzáértés növelése" ebben az időben jelent meg a pedagógusképzésben is. Legelőször talán a tanítóképzésben. Ezen a területen - a Nemzeti alaptanterv munkálataival párhuzamosan - 1994-ben (158/1994/XI:7/ sz.) kormányrendelet jelent meg az új, négyéves képzési követelményekről. A követelményrendszer erőteljesen interdiszciplináris volt, azaz müveltségi területekben strukturálta az ismereteket és a képességeket. Említést érdemel, hogy a képzési követelményeket hatásvizsgálatok alapján készítették el, ami kétség kívül „úttörő" vállalkozás volt a hazai felsőoktatásban. Ez egyszerre jelentette a tanítóképzés tartalmi és képzési megújulását (Bollókné és Hunyady, 2003; Hunyady, 2000).

Az 1995-ben elkészült Nemzeti alaptantervet a kormányrendelet formájában 1998. szeptember 1-jével az 1. és a 7. évfolyamon vezették be [130/1995. (X. 26.) Korm. rendelete a Nemzeti alaptanterv kiadásáról]. Az 1995-ben, hosszas egyeztetések és viták után elkészített Nemzeti alaptanterv számos új elemet tartalmazott, amely nemcsak a közoktatás számára jelentett komoly kihívást, hanem a pedagógusképzésre is hatással volt. Mindenekelött érdemes kiemelni azt a tényt, hogy a korábbi központi szabályozást egy kétpólusú rendszer váltotta fel, amely felértékelte a pedagógusok tantervfejlesztési kompetenciáit. A decentralizált irányítás azt is jelentette, hogy az iskolai pedagógiai programok elkészítése korábban sosem tapasztalt döntési lehetőséget jelentett az intézmények számára. Dönthettek az iskola profiljáról, stratégiájáról, a legfontosabb értékekről, a tantárgyakról, a tantárgyak integrálásáról és az óraszámokról, a helyi programokról. A Nat-1995 - először a hazai tantervtörténetben - a tananyagot, a követelményeket, a fejlesztendö képességeket közös követelményekben (kereszttantervek) és müveltségi területekben jelenítette meg. A hét közös követelmény, a tíz müveltségi terület és a 23 részmüveltségi terület számos tantárgyfelosztási kombinációt eredményezett. Ráadásul a Nat-1995 a müveltségterületi elrendeződés mellett az időkereteket százalékos arányokban és nem kötelező óraszámokban ajánlotta az iskolák számára. Ez olyan módszertani, tananyag-elrendezési és iskolaszervezési, -fejlesztési folyamatokat indított el a közoktatás egészében, amely a pedagógusképzés tartalmára is hatással volt. A Nat1995 alapelveiben, értékrendszerében és müveltségképében (lásd a korábban említett közös követelményeket és müveltségterületi elrendezödést) az interdiszciplináris 
tudást, az integratív szemléletet erősítette. Ez mind a közoktatás, mind a pedagógusképzés számára komoly kihívást jelentett. Ugyanakkor nem elhanyagolható az a tény sem, hogy a Nemzeti alaptanterv bevezetése és a pedagógusképzés megújulása egymással párhuzamosan történt. Egymást erösítő és egymásra ható folyamatok zajlottak le. Ekkor jelent meg a pedagógusképzés reformjában jelentős szerepet játszó rendelet, az ún. „111-es” (111/1997-es kormányrendelet). A koncipiálási-modellezési folyamatok elindultak. A pedagógusképzés stratégiai kérdéseiről bizottságok, szakmai mühelyek élénk vitákat folytattak. ${ }^{3}$ Érdemes leszögezni, hogy a Nat-1995 implementációja után mind a müveltségpedagógiai, interdiszciplináris, mind a képességeket hatékonyabban fejlesztő módszertant és tanulásszervezést elötérbe helyező képzések tekintetében pusztán sporadikus törekvések mutathatók ki. ${ }^{4}$ A kívánatos pedagógiai változások csak a deklarált tantervek (alaptanterv, helyi tantervek) szintjén jelentek meg. A pedagógusképzésben hasonló volt a helyzet. A jogi-szabályozó környezet megváltozása és a stratégiai elvek rendszerezése után a közoktatási és a pedagógusképzési gyakorlat támogatása következett.

Az oktatási miniszter 2002 decemberében a Közoktatási törvény 93.§ (1) alapján elrendelte a Nat-1995 fölülvizsgálatát. Ennek értelmében értékelte a Nemzeti alaptanterv bevezetésével és alkalmazásával kapcsolatos tapasztalatokat, $\mathrm{s}$ kezdeményezte a tanterv módosítását. Szakmai szempontból fontos célkitüzés volt a Nat1995 pozitív vonásainak megerősítése, s az ellentmondások feloldása. A megújult dokumentum megörizte alaptantervi, stratégiai jellegét, ugyanakkor lényegesen megerösödött a tanterv fejlesztő funkciója. A 243/2003. (XII. 17.) Kormányrendelet rendelkezett a Nemzeti alaptanterv kiadásáról, bevezetéséről és alkalmazásáról, meghatározta a tartalmi szabályozás rendszerét is. A Nat-2003 bevezetése felmenő rendszerben, 2004. szeptember 1-jével az általános iskolák első évfolyamán vette kezdetét. A tantervi-pedagógiai fejlesztés folyamatban történő végiggondolása, valamint a tanulói tevékenykedtetés, a learning by doing elv erősítése alapvető célkitüzése volt a felülvizsgálatnak. A Nat-1995 általános fejlesztési feladatainak markánsabbá tétele és a részletes követelményrendszer átstrukturálása azt is eredményezte, hogy az alaptanterv elsősorban a fejlesztendő kompetenciákra fókuszált. Kiemelte a „kommunikációs, a narratív, a döntési, a szabálykövető, a lényegkiemelő, az életvezetési, az együttmüködési, a problémamegoldó, a kritikai, valamint a komplex információk kezelésével kapcsolatos képességeket, kulcskompetenciákat." Ez a kompetencia-lista meghatározó volt egyrészt a Nemzeti alaptanterv kiemelt és müveltségterületi fejlesztési feladatainak felülvizsgálata terén, másrészt hatással volt a pedagógus-kompetenciák kidolgozására is.

\footnotetext{
${ }^{3}$ Lásd Báthory Zoltán, Loránd Ferenc, Hunyady György és Zsolnai József tanulmányait. Pedagógusképzés 2003, 1-2. Később a tanulmányok föbb gondolatait részletesen elemzem.

4 Lásd az Eötvös Loránd Tudományegyetem Neveléstudományi Intézetének képzési programját a 2001/2002. tanévben. Publikálta: Golnhofer Erzsébet: Törekvés a tanárképzés megújítására. Pedagógusképzés, 2003, 1-2.sz. 101-107.
} 
A Nat-2003 az integratív és a tantárgyközi szemlélet (kiemelt fejlesztési feladatok, 10 mủveltségterület) megtartására és a képességek hatékonyabb fejlesztésére helyezte a hangsúlyt. A Nat-2003 felvállalta a Nat-1995 szellemi örökségét és a tíz müveltségi területet (mint a NAT alapszerkezetét), ám attól néhány szakmai kérdésben mégis eltért. A fontosabb különbségek a következők:

a) A Nat-2003-ból kimaradtak a müveltségterületi „,részletes követelmények”.

b) A tervezetben a korábbinál nagyobb hangsúlyt kaptak a „kiemelt fejlesztési feladatok” és a „kulcskompetenciák”.

c) A tervezet átfogta a közoktatás teljes vertikumát az elsőtől a tizenkettedik évfolyamig.

d) Megváltozott az egyes müveltségi területek belső logikájának kifejtése.

e) A Nat-2003 végén egy definíciós lista segítette a közös megértést és kommunikációt.

Ugyanakkor az iskolai pedagógiai programok ,életre keltése” fontos feladat volt. A nagymértékü tantervi adaptációs gyakorlaton is változtatni kellett. A tantervi minták mellett (a tantervi-tartalmi szabályozás középső szintjén) megjelentek az oktatási programok, programcsomagok, pedagógiai rendszerek. A Nat-2003 - a tartalmi szabályozással összefüggő - definíciója szerint „a tanítás-tanulás megtervezését-megtervezését segítő, választható dokumentumok, szakmai eszközök rendszerérool" van szó. A rendszer kerettantervi, pedagógiai koncepció, modulleírás, eszközi elem, értékelési eszköz, továbbképzési program, támogatás komponenseket egyaránt tartalmaz. Nem pusztán tantervi, hanem pedagógiai (tanulásszervezési, módszertani és tananyag-strukturálási) támogatást is biztosít az iskolák számára. Az új alaptanterv mindemellett az osztálytermi folyamatok és a személyre szabott fejlesztés hatékonyabb támogatását is célul tüzte ki.

Mi a helyzet a pedagógusképzés területén? A Nat-2003 folyamataival párhuzamosan a hazai pedagógusképzés átalakulása is folytatódott. A bolognai folyamatnak köszönhetően, az akkreditációs elöírások révén strukturális változások indultak el, a képzések szerkezete megváltozott. Elkezdődtek azok a munkálatok is, amelyek egy egységes pedagógus kompetencia-lista megalkotását célozták meg. Hasonlóan a Nat-1995 folyamataihoz, ebben az esetben is - 2005-ben - az óvó- és tanító szakot akkreditálták először. A képzési és kimeneti követelményekben, illetve a konzorcium keretében kidolgozott indítási dokumentumokban a Nat-2003 szellemiségének és a kezdőszakasz meghosszabbodásának megfelelően már kompetenciákat találunk. Tovább erősödött a képzés integratív jellege, müveltségterületi alapozottsága. Előtérbe került az alapképességek fejlesztésének pedagógiája.

Az első eredmények a Nat-1995 2003. évi felülvizsgálata idején már megmutatkoztak. Számos ponton felbukkantak és rendszerszerúen megfogalmazódtak a „változó közoktatás igényei” és a pedagógusképzésre gyakorolt hatások. Az összefüggések könnyebb átlátása érdekében Hunyady György a változásokat öt csoportba osztotta. A (1) demográfiai változások és a kötelező iskolázás kiterjesztése, (2) tár- 
sadalmi-gazdasági változások, (3) az életfeltételek átalakulása különös tekintettel az informatika és az emberi-családi kapcsolatok területeire, (4) az oktatás tartalmi szabályozása, (5) az iskolarendszer átalakulása. Az oktatás tartalmi szabályozásával kapcsolatban megemlíti, hogy a Nat-2003 „távol tartja magát az iskolai tananyag tartalmi részleteitől, csak a kifejlesztendő kompetenciák alakítására ügyelve átfogó, ,műveltségterületekre' helyezi a hangsúlyt, s (a tantervírók és iskolai programkészítők számára) a diszciplínákhoz kötődő hagyományos tantárgyak integrációját sugallja." (Hunyady, 2003, 80. o.) Ez az interdiszciplináris szemlélet markánsan megjelenik Báthory Zoltán és Zsolnai József pedagógusképzési modelljeiben. Báthory javaslatot tesz interdiszciplináris kisszakokra. Például a magyar nagyszak mellett drámapedagógia, médiapedagógia és kommunikáció szakokra. Zsolnai József felteszi a kulcskérdést: „meddig képezünk fizika, kémia, biológia, földrajz, testnevelés szakos tanárokat, és mikor kerül sor anyanyelv- és irodalompedagógusok, embertan- és társadalompedagógusok, embertan- és természetpedagógusok, embertan- és környezetpedagógusok, matematikapedagógusok, informatikapedagógusok, életvitel- és technikapedagógusok, testnevelés- és sportpedagógusok stb. képzésére" (Zsolnai, 2003, 92. o.). Ladányi Andor szerint a „NAT tíz műveltségi területe közül a magyar nyelv és irodalom, az élő idegen nyelv, a matematika, az informatika, a testnevelés és sport esetében megfelelő tanári szakok vannak. Szükséges azonban ezek curriculumának a módosítása a NAT követelményeinek figyelembevételével, valamint kiegészítése valamely új müveltségi terület körébe tartozó részterület ismeretanyagával" (Ladányi, 2003. 49. o.). A többi öt műveltségi terület esetében már differenciáltabb megoldásokat javasol.

Összegezve a Nemzeti alaptanterv fejlödéstörténetének (1995-2003) és az ezzel párhuzamosan zajló pedagógusképzési folyamatoknak az elemzését, érdemes a Nat1995 és a Nat-2003, valamint a pedagógusképzés hasonlóságaira és eltéréseire fókuszálni (lásd 1. táblázat). A két alaptanterv hasonlóságai elsősorban az integratív személetben (közös követelmények, majd kiemelt fejlesztési feladatok, müveltségi területek) ragadhatók meg. Ugyanakkor jelentős eltérés mutatkozik abban, hogy a Nat-1995 elötérbe helyezte a részletes követelményeket (tananyag, fejlesztési követelmények, minimális teljesítmény), a Nat-2003 már a kulcskompetenciákra épített. A fejlesztés folyamatának hosszában is mutatkozik eltérés a két alaptanterv között. Az előbbi 10, míg az utóbbi 12 évre szabályoz. Kétségkívül összefüggésben van ez a tankötelezettség 16 évről 18 évre történő meghosszabbításában. Ám tantervelméleti szempontból ennél többről van szó. A Nat-2003 már közelít a curriculum múfajához (folyamatterv, tevékenységterv, program). A fejlesztési folyamatban történő gondolkodásra helyezi a hangsúlyt. A pedagógusképzésben az 1990-es évek végén elötérbe került a tantervelméleti és -fejlesztési tudás növelésének igénye. Ez együttjárt a pedagógusjelöltek tantervfejlesztési kompetenciáinak az erősítésével. Ugyanakkor 2003-ig a pedagógusképzésben elindult egyrészt egy interdiszciplináris, strukturális átalakulás, másrészt több-kevesebb sikerrel megvalósult 
egy másfajta módszertani kultúrát erősítő képzés. Előtérbe kerületek a megváltozott pedagógusszerepek és pedagógiai nézetek kutatásai.

1. táblázat: A Nemzeti alaptanterv fejlődéstörténete (1995-2003) és a pedagógusképzési folyamatok

\begin{tabular}{|l|l|l|}
\hline & \multicolumn{1}{|c|}{ Nat-1995 } & \multicolumn{1}{c|}{ Nat-2003 } \\
\hline Hasonlóságok & \multicolumn{1}{|c|}{$\begin{array}{c}\text { Integratív szemlélet (közös követelmények majd kiemelt } \\
\text { fejlesztési feladatok, müveltségi területek) }\end{array}$} \\
\hline Eltérések & $\begin{array}{l}\text { Részletes követelmények } \\
\text { (tananyag, fejlesztési } \\
\text { követelmények, minimális } \\
\text { teljesítmény) } \\
10 \text { évre szabályoz } \\
\text { Kismértékben curriculum } \\
\text { (folyamatterv, tevékenységterv, } \\
\text { program) }\end{array}$ & $\begin{array}{l}\text { Kulcskompetenciák listája } \\
\text { (folyamatterv, } \\
\text { (t) évre szabályoz } \\
\text { tevékenységterv, program) }\end{array}$ \\
\hline $\begin{array}{l}\text { Pedagógusképzési } \\
\text { fókuszok }\end{array}$ & $\begin{array}{l}\text { Tantervelméleti és -fejlesztési } \\
\text { tudás } \\
\text { Tantervfejlesztési kompetenciák } \\
\text { erósítése }\end{array}$ & $\begin{array}{l}\text { Interdiszciplináris szakok } \\
\text { Módszertani kultúra }\end{array}$ \\
\hline & \multicolumn{2}{|c|}{ Pedagógusszerepek, pedagógiai nézetek } \\
\hline
\end{tabular}

\section{A Nat-2007 és a pedagógusképzés összefüggései}

A Nat-2003 felülvizsgálatát a Közoktatási törvény változásai mellett egyfelől a PISAvizsgálatok tudáskoncepciója és kompetencia-alapú követelményrendszere, másfelöl az Európai Unió kulcskompetencia keretrendszere határozta meg. ${ }^{5}$ Az Európai Unió politikájában szabályozási és fejlesztési prioritás lett egy olyan szisztéma megalkotása, amely a gazdaság világában és a modern társadalomban történő boldoguláshoz, a tudás megszerzéséhez és megújításához, az élethosszig tartó tanulás paradigmájához, a müveltség igényének kialakulásához, valamint a személyes önmegvalósításhoz szükséges kompetenciákat tartalmazza. A Nat-2007-ben kilenc kulcskompetencia jelenik meg:

1. Anyanyelvi kommunikáció

2. Idegen nyelvi kommunikáció

\footnotetext{
${ }^{5}$ A Nemzeti alaptantervben megjelenő kulcskompetenciák alapját a RECOMMENDATION OF THE EUROPEAN PARLIAMENT AND OF THE COUNCIL of 18 December 2006 on key competences for lifelong learning (2006/962/EC) c. dokumentum képezi.
} 
3. Matematikai kompetencia

4. Természettudományos kompetencia

5. Digitális kompetencia

6. A hatékony és önálló tanulás kompetenciája

7. Szociális és állampolgári kompetencia

8. Kezdeményezőképesség és vállalkozói kompetencia

9. Esztétikai-művészeti tudatosság és kifejezőképesség

A kulcskompetenciák strukturálódtak (definíció, ismeretek, képességek, attitüdök), az iskolai múveltség és tudás tartalmának irányadó kánonja a kulcskompetenciák rendszere lett. Fontossá vált a kulcskompetenciák fejlesztése, az egész életen át tartó tanulásra, ezen belül az egyéni tanulás képességének folyamatos megújítására való felkészítés. A kiemelt fejlesztési feladatok bővültek (aktív állampolgárságra, demokráciára nevelés; gazdasági nevelés). A tíz müveltségi terület bevezetője változott, fejlesztési feladatai csak kis mértékben módosultak. Erősödött a Nemzeti alaptanterv integratív szemlélete. Ez a Nat-evolúció egyik fő jellemzője. Ugyanakkor a tanítás módszertanáról alapvetően a tanulás tervezésére, fejlesztésére és értékelésére helyeződött a hangsúly. Mit jelent ez a pedagógusképzést tekintve? Az alapképzési és mesterképzési szakok, ezen belül a tanári szakképzettségek Képzési és Kimeneti Követelményei (KKK) létrejöttek. ${ }^{6}$ Falus Iván szerint „a pedagógusképzés és -továbbképzés területén elengedhetetlen feladatnak látszik a kognitív alapokon nyugvó kompetencia/sztenderd rendszerek meghatározása, s ezek szaktárgyi adaptációja; a sztenderdek alapján a tantárgyak összerendeződése, az elérésükhöz szükséges feladatok rendszerének meghatározása, az értékelésükre alkalmas portfóliók elkészítése; a bevezető szakasz feltételeinek megteremtése, a fejlesztési profóliók kidolgozása." (Falus, 2006, 146. o.). A tanári kompetenciák tartalma leírásra került (tudás, képesség, attitüdök/nézetek), a sztenderdizálási folyamatok beértek, a tanári szakok követelményrendszerébe beépültek. ${ }^{7}$

Annak érdekében, hogy a közeljövő legfontosabb feladatait, területeit felvázolhassam, érdemes a Nat-2007 és a pedagógusképzés összefüggéseit röviden öszszegezni (lásd 2. táblázat). A Nat-2007 és a pedagógusképzés kimeneti követelményei esetében jól megragadható a kompetencia-alapú fejlesztésre törekvés. Ez nem pusztán a kompetenciák felsorolása, hanem azok strukturálása. A struktúrák lehetővé teszik azt, hogy mind a Nat-2007 kulcskompetenciái, mind a tanári kompetenciák (tantervfejlesztési kompetenciák) a fejlesztés gyakorlatában is hatékonyabban jelenjenek meg. A fejlesztési folyamatban történő gondolkodás (tervezés, fejlesztés, értékelés) jól kimutatható mind a Nat-2007, mind a pedagógusképzés esetében. A Nat-2007 a hatékony és önálló kulcskompetencia fejlesztésében látja az alaptan-

\footnotetext{
${ }^{6}$ Oktatási Közlöny 2007. október 24.

${ }^{7}$ Ezen a területen jelentős Falus Iván munkássága. (Lásd: Falus, 2006, 2007)
} 
tervi implementáció (bevezetés, elterjesztés, harmonizáció, begyökereztetés) egyik fontos feladatát.

A Nemzeti alaptanterv implementációjának azt a több évig tartó szisztematikus folyamatot nevezzük, amelyben a Nat-2007 legfontosabb célkitüzései, az alaptanterv egész szemlélete az iskolai gyakorlatban megvalósul. Az implementáció funkciója egyfelől a tartalmi szabályozási rendszer egyes elemeinek (kerettantervek, oktatási programok, állami vizsgakövetelmények, mérési-értékelési feladatok, tankönyvek, taneszközök, iskolai pedagógiai programok) integrálása, harmonizációja a közös müveltségi alapok, tudáskoncepció és tanulásfelfogás mentén, másfelől a Nemzeti alaptanterv megvalósulásának, bevezetésének segítése, támogatása. ${ }^{8}$ A pedagógusképzés sztenderdjei között is nagy hangsúlyt kap az önszabályozó tanulás, a képzésben résztvevők tanulási kompetenciáinak diagnosztizálása, a fejlődés nyomon követése. A Nat-2007 integratív személete markánsan megjelent a müveltségterületi szakterületek esetében (v. ö. Ember és társadalom).

2. táblázat: A Nat-2007 és a pedagógusképzés összefüggései

\begin{tabular}{|l|c|c|}
\hline & Nat-2007 & Pedagógusképzés \\
\hline Kompetencia-alapúság & kulcskompetenciák & $\begin{array}{c}\text { tanári kompetenciák, } \\
\text { sztenderdek, KKK-k }\end{array}$ \\
\hline Kompetenciastruktúrák & $\begin{array}{c}\text { ismeretek, képességek, } \\
\text { attitüdök }\end{array}$ & $\begin{array}{c}\text { tudás, képesség, } \\
\text { attitüd/nézetek }\end{array}$ \\
\hline Fejlesztési folyamat & \multicolumn{2}{|c|}{ tervezés, fejlesztés, értékelés } \\
\hline Tanulás & hatékony és önálló tanulás & $\begin{array}{c}\text { önszabályozó tanulás, } \\
\text { diagnosztizálás, a fejlödés } \\
\text { nyomon követése }\end{array}$ \\
\hline Integratív szemlélet & $\begin{array}{c}\text { kiemelt fejlesztési feladatok, } \\
\text { müveltségi területek }\end{array}$ & $\begin{array}{c}\text { müveltségterületi } \\
\text { szakterületek }\end{array}$ \\
\hline
\end{tabular}

A Nat-evolúció és a pedagógusképzés fenti folyamatainak bemutatása, az összefüggések elemzése után lehetővé válik a közeljövő feladatainak és területeinek a felsorolása.

1. A képzők, a mentorok és a pedagógusjelöltek közötti hatékonyabb, tudatosabb együttmüködés segíti azt, hogy a közoktatás tartalmi reformja és a pedagógusképzés gyakorlata között erőteljes legyen a koherencia.

\footnotetext{
${ }^{8}$ A Nemzeti alaptanterv implementációja. Összeállította: Vass Vilmos. Az anyag összeállításában közreműködött: Báthory Zoltán, Brassói Sándor, Halász Gábor, Mihály Ottó, Perjés István, Vágó Irén. Budapest, 2008. március (az Oktatási és Kulturális Minisztérium kérésére készített munkaanyag)
} 
2. A tantervfejlesztési kompetenciák között kiemelt figyelmet kell kapnia az interdiszciplináris pedagógiára vonatkozó ismereteknek és a hozzá kapcsolódó képességeknek. Nevezetesen a pedagógusképzésben markánsan jelenjenek meg azok a tantárgyközi tantervi tervező, fejlesztő, értékelö technikák és eszközök, amelyek lehetővé teszik azt, hogy a Nemzeti alaptanterv integratív személete a közoktatás gyakorlatában is erőteljesebben érvényesüljön.

3. A hatékony és önálló tanulás kulcskompetencia fejlesztése mind a közoktatásban, mind a pedagógusképzésben kiemelt feladat. A kulcskompetenciák és a tanári kompetenciák fejlesztése ennek érdekében történik. A pedagógusképzésben kiemelt figyelmet kell kapnia - a tanuláselméletek és modellek megismertetése mellett - a hatékony és önálló tanulás kulcskompetencia tervezését, fejlesztését és értékelését támogató technikák és eszközök használatának. Ugyanakkor elengedhetetlen a képzésben résztvevők tanulási kompetenciáinak a diagnosztizálása, az önszabályozó tanulás segítése, a fejlődésük nyomon követése (tanulási naplók, portfóliók, fejlesztő értékelö lapok).

Összegezve megállapítható, hogy a hazai tantervi változásokban folyamatosság, egyfajta „evolúciós tendencia” mutatható ki. A tantervi-tartalmi reform és a pedagógusképzés átalakulása egymással párhuzamos, egymást erősítő folyamat. A tantervi és képzési innovációk hazánkban alulról-felfelé indultak el. Az iskolák önállósodása, kísérletező kedve megerősítést kapott, melyet a Nat-1995 bevezetése is támogatott. Vertikális szempontból a tartalmi szabályozás kétpólusú (központi, helyi), háromszintü (alaptanterv, kerettanterv/oktatási programcsomag, helyi tanterv) rendszerré alakult. Horizontális szempontból a tananyag- és követelményközpontú tanterv egyre inkább tevékenységközpontú, kompetencia-alapú folyamatterv lett. A kulcskompetenciák és a tanári kompetenciák strukturálódtak, a kiemelt fejlesztési feladatok bővültek. A Nemzeti alaptanterv integratív szemlélete erősödött, az interdiszciplináris tendenciák a pedagógusképzésben is megjelentek. A tanítás módszertanáról alapvetően a tanulás tervezésére, fejlesztésére és értékelésére helyeződött a hangsúly. Ez a pedagógusképzés gyakorlatára is hatott és a közeljövő feladatait is befolyásolja.

\section{Irodalom}

Ballér Endre (2003): A tanterv. In: Falus Iván (Szerk.): Didaktika. Elméleti alapok a tanitás tanulásához. Nemzeti Tankönyvkiadó, Budapest, 191-218.

Ballér Endre (2004): A tantervelmélet útjain. Válogatás négy évtized pedagógiai irásaiból. AULA Kiadó, Budapest.

Báthory Zoltán (2000): Tanulók, iskolák - különbségek. Egy differenciált tanitáselmélet vázlata. OKKER Oktatási Kiadó, Budapest. 
Báthory Zoltán (2001): Maratoni reform. A magyar közoktatás reformjának története, 19722000. ÖNKONET Kiadó, Budapest.

Báthory Zoltán (2003): Válságban a pedagógusképzés - a közoktatás felől nézve. Pedagógusképzés 1-2. sz. 63-71.

Bollókné Panyik Ilona - Hunyady Györgyné (2003): A tanítóképzés az integrált felsőoktatásban. Új Pedagógiai Szemle, 6-7. sz. 4-17.

Falus Iván (2005): Képesítési követelmények - kompetenciák - sztenderdek. Pedagógusképzés, 1. sz. 5-16.

Falus Iván (2006): A tanári tevékenység és a pedagógusképzés új útjai. Gondolat Kiadó, Budapest.

Falus Iván (szerk., 2007): A tanárrá válás folyamata. Gondolat Kiadó, Budapest.

Hunyady György (2003): A hazai tanárképzés stratégiai problémái. Pedagógusképzés, 1-2. sz. 77-89.

Hunyady Györgyné (2000): A négyéves „tanító” szak programja: Bevezetés és kommentár. In: Kovátsné Németh Mária (szerk.): Óvó- és tanitóképzés az ezredfordulón. Tanító- és Óvóképző Főiskolák, Főiskolai Karok Kollégiuma; Óvó- és Tanítóképzők Egyesülete, Kaposvár, 89-101.

Ladányi Andor (2003): A NAT és a tanárképzés. Új Pedagógiai Szemle, 1. sz. 47-53.

Loránd Ferenc (2003): A közoktatás távlati igényei a pedagógusképzéssel szemben. Pedagógusképzés, 1-2. sz. 71-77.

Nemzeti alaptanterv (1995): Művelődési és Közoktatási Minisztérium, Budapest.

Nemzeti alaptanterv (2003): Oktatási Minisztérium, Budapest.

Nemzeti alaptanterv (2007): Oktatási és Kulturális Minisztérium, Budapest.

Pőcze Gábor (1995): A NAT és a gyakorlat - A Nemzeti alaptanterv implementációja. Új Pedagógiai Szemle, 4. sz. 12-36.

Szebenyi Péter (1994): Tantervkészítés egykor és most. Educatio, 3. sz. 345-354.

Vass Vilmos (2003): A Nemzeti alaptanterv felülvizsgálata. Új Pedagógiai Szemle, 6. sz. $40-44$.

Vass Vilmos (szerk.) (2008): A Nemzeti alaptanterv implementációja. Kézirat.

Zsolnai József (2003): Az egységes pedagógusképzés koncepciója és kivitelezésének lehetőségei a Veszprémi Egyetemen. Pedagógusképzés, 1-2. sz. 89-101. 